Reprod. Nutr. Dévelop., 1983, 23 (1), 145-149.

\title{
The relation of nucleic acids to condition factor in the catfish, Heteropneustes fossilis
}

\author{
S. MUSTAFA, S. M. ZOFAIR
}

Division of /chthyology and Fisheries, Department of Zoology Aligarh Muslim University, Aligarh 202001, India

Summary. The aim of this study was to determine the relationship between RNA and DNA concentrations in body tissue and the condition factor in the catfish, Heteropneustes fossilis. RNA was related curvilinearly to condition, while DNA maintained a reciprocal relation. The biochemical basis of changes in condition and the effect of these changes on tissue specific gravity have been discussed and the relationships determined.

\section{Introduction.}

The condition factor is basically used to give an indication of the relative heaviness of the fish. However, this factor is a quantitative measure, for a given length, of the deviation of the mass of an individual from the average mass, and it fails to reveal accurately the underlying qualitative changes in the body which may be true indicators of the physiological or nutritional status of the fish. Recent years have witnessed a surge of interest in the use of certain significant biochemical constituents as indices of the condition or general well-being of fish. The aim of the present study was to determine the relationship between RNA and DNA concentrations and specific gravity of the flesh on the one hand and the condition factor (fillet condition factor) on the other in Heteropneustes fossilis (Bloch), an air-breathing catfish.

\section{Material and methods.}

Live specimens of catfish $25 \pm 0.68 \mathrm{~cm}$ long (mean \pm SE) and with a body weight of $105.3 \pm 8.62 \mathrm{~g}$ (mean \pm SE) were collected from local ponds at Aligarh (Lat. 27 $34^{\prime} 30^{\prime \prime} \mathrm{N}$, Long. $78^{\circ} 4^{\prime} 26^{\prime \prime} \mathrm{E}$ ) and transferred to glass aquaria. They were fed to satiety by providing chopped meat at the rate of $3 \%$ of body weight per day. Unused food was siphoned off. Since males were not available in adequate numbers, only females were used in this study. At the time of investigation the fish were taken out of the aquaria and decapitated. The fillets were removed and weighed on sensitive electric scales. The fillet condition factor (C) 
was calculated according to the equation adopted by Wilkins (1967) and Mustafa and Jafri (1981):

$$
C=\frac{W}{L^{3}} \times 1000
$$

where $W$ is the weight $(\mathrm{g})$ and $L$ the length $(\mathrm{cm})$ of the fillet. Specific gravity of white trunk muscle was determined according to the technique of Hasan and Jafri (1964) and Jafri et al. (1976), using the ratio : mass of tissue/mass of an equal volume of distilled water. A sample of white muscle for RNA and DNA analysis was removed from the epaxial portion of the trunk below the site of origin of the dorsal fin. Care was taken to avoid intermingling red muscle fibers. The fact that red and white muscles differ in nucleic acids and other biological constituents is amply clear from the work of Mustafa (1977a, 1978) and Shams (1980). The former author warned against taking unspecified parts of the fillet for chemical analysis as the anatomical heterogeneity of mixed samples is an influential factor and can easily skew data obtained by biochemical analysis.

For nucleic acid assays dry fat-free tissue was obtained according to the technique of Webb and Levy (1955). RNA was extracted and estimated following the method of Schneider (1957) based on the reaction of orcinol with the pentose sugar of the RNA. Values were calculated using a calibration curve comparing the optical density of RNA (micrograms) to purified yeast RNA serving as the standard.

For the extraction of DNA, a measured weight of dry fat-free sample was suspended in a known volume of $5 \%$ trichloroacetic acid. This suspension was heated in a boiling water-bath for $30 \mathrm{~min}$ and then cooled to room temperature in running tap water. Loss of volume during boiling was compensated by adding the needed amounts of $5 \%$ cold trichloroacetic acid. The sample was filtered and the DNA quantitated in the filtrate according to the technique of Ashwell (1957). With this method the cysteine-sulphuric acid reagent reacts with deoxy sugars of DNA to develop a pinkish color. The values were read off against a standard curve prepared with highly polymerized calf thymus DNA. Color intensities were read on a Bausch and Lomb Spectronic 20 Spectrophotometer. These biochemical techniques have been successfully used by the senior author in earlier work (Mustafa, 1977a, b ; 1978 ; Mustafa and Mittal, 1982 ; Mustafa and Shams, 1982). RNA and DNA values were expressed in $\mu \mathrm{g} / 100 \mathrm{mg}$ on a dry fatfree weight basis.

The relationships between different parameters (RNA, DNA, specific gravity, respectively) on the one hand and condition on the other were evaluated by standard regression equations using the least-squares method. The results were based on 25 observations.

\section{Results and discussion.}

Our results show that RNA concentration increased with the fillet condition factor, while that of DNA decreased exponentially (fig. 1); the relation of RNA 
was of a more curvilinear type. The method of graphic approximation of these two parameters (RNA and fillet condition factor) gives a good visual idea of the existing relationship but the empirical derivation of the value of one parameter from a given value of the other using the regression equation :

RNA, $\mu \mathrm{g} / 100 \mathrm{mg}=159.487+255.280 \mathrm{C}$ (correlation coefficient $=0.722$ ) is not pertinent as the slope is not straight and the curve can be divided into segments, each being nearly rectilinear and having its own value. Therefore, there was a discrepancy between the RNA values for a particular condition evidenced on the graph and the ones calculated by the equation. The corrective factor with which the empirically computed value was multiplied varied between 0.9 and 1.03 .

In an earlier paper Mustafa (1979) reported a linear relation between RNA and fillet condition factor in a murrel, Channa punctatus, and proposed an equation describing this relation. However, Shams (1980) working on the catfish, Clarias batrachus, suggested caution in seeking statistical relations of universal importance using regression model patterns. In view of RNA involvement in protein biosynthesis and hence growth, increase in RNA with fillet condition factor is also an indication of the effect of this nucleic acid on the robustness of fish. The work of Mustafa (1979) on the relation of RNA and protein to condition and the strikingly close relationship between these two components strengthens this view. The correlation between RNA turnover and growth rate of fish is also well established.

During weight gain for a given length, the nutrients (chiefly protein) evidently accumulate in the cell cytoplasm and orient the specific gravity of the tissue towards a definitive increase (fig. 1). The formula describing the relation of specific gravity to fillet condition factor is :

specific gravity $=0.870+0.109 \mathrm{C}$ (correlation coefficient $=0.744$ ) .
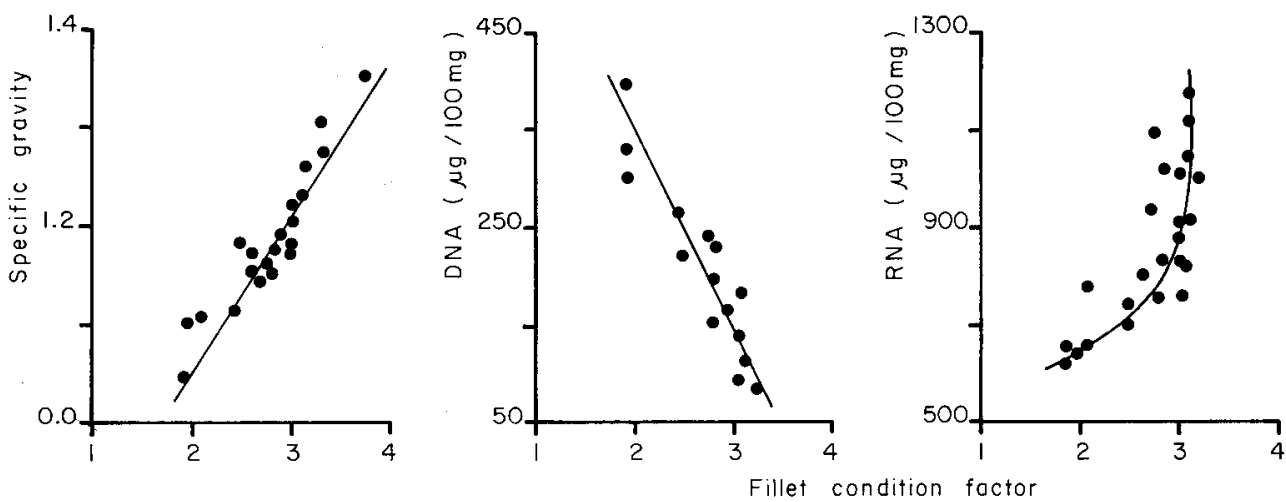

FIG. 1. - Relations of specific gravity and RNA and DNA concentrations to fillet condition factor in Heteropneustes fossilis.

Muscle tissue obtained from a fish with higher fillet condition has higher specific gravity. However, it must not be forgotten that specific gravity may be altered by many cellular components besides protein, like fat, water and ash. 
Undoubtedly, the influence of protein is dominant. In any case, this variation in the specific gravity of fish tissue limits the applicability of the cube law in fishery investigations involving the length-weight relationship and the condition of fish.

The decline in DNA concentration with increase in fillet condition factor (fig. 1) in the present study does not contradict the generally accepted view of the metabolic stability of this genetic material. The apparent decrease is in the ratio of amount/unit weight of tissue and not in the DNA content/cell ratio. The regression equation establishing the relation between the two parameters is : DNA, $\mu \mathrm{g} / 100 \mathrm{mg}=668.199-170.116 \mathrm{C}$ (correlation coefficient $=-0.865$ )

Since quantitative increase in fillet weight and condition is a function of the accumulation of biochemical constituents in cells in the form of cytoplasmic inclusions (evidenced by a rise in the specific gravity of muscle tissue), a given volume of tissue becomes heavier than the equivalent volume of the sample excised from a fish of low condition factor whose cytoplasmic reserves are smaller and of lower specific gravity. Compared to a larger number of cells of lower weight, a smaller number of higher-weight cells can contribute to the unit weight of a sample. DNA content, which is related to the number of cells in the tissue, is greater in tissue samples from depleted fish (in poor condition) than in samples from robust specimens (in good condition) in which DNA seems to be diluted by the accumulation of substantial quantities of several nutrients in the cells.

The above discussion leaves no doubt that the equations expressing the relation of the condition factor of catfish to tissue nucleic acids and specific gravity permit rapid assessment of even short-term changes in growth and of the general state of cultured fish. Field biologists and fisheries management scientists require such a reliable factor to determine the condition of fishes after environmental alterations and to monitor the effects of changes in the food supply or its consumption by fish.

Reçu en juillet 1982.

Accepté en septembre 1982.

Résumé. Acides nucléiques et "facteur de condition " chez le Poisson chat Heteropneustes fossilis.

Cette étude a pour but de déterminer la relation entre les concentrations tissulaires en ARN et ADN d'une part, et le " facteur de condition " d'autre part, chez le Poisson chat Heteropneustes fossilis. Cette relation n'est linéaire que dans le cas de I'ADN. Les bases biochimiques des changements de " condition » et l'effet de ces changements sur le poids spécifique des tissus sont discutés.

\section{References}

ASHWELL G., 1957. Colorimetric analysis of sugars : cysterine reaction of DNA. In COLOWICK S. P., KAPLAN N. O. Methods in enzymology, Vol. 3, Acad. Press, New-York, NY. HASAN R., JAFRI A. K., 1964. A physico-chemical analysis of ripe, unspawned eggs of some freshwater teleosts. Proc. indian Acad. Sci., 9, 1-11. 
JAFRI A. K., MUSTAFA S., AHMAD I., 1976. Some physical properties of the muscle lipid of two freshwater teleosts Ophicephalus striatus Bloch and Clarias batrachus (Linn). Fish Technol., 13, 73-75.

MUSTAFA S., 1977a. Nucleic acid turnover in dark and white muscles of some freshwater species of carps during growth in the prematurity phase. Copeia, $n^{\circ} 1,173-176$.

MUSTAFA S., 1977b. Influence of maturation on the concentrations of RNA and DNA in the flesh of the catfish Clarias batrachus. Trans. am. Fish. Soc., 106, 449-451.

MUSTAFA S., 1978. Deoxyribose nucleic acid in the musculature of freshwater catfish Heteropneustes fossilis (Bloch). Broteria, 48, 83-92.

MUSTAFA S., 1979. RNA and synthesis of protein in relation to "biological condition " of freshwater teleost, Channa punctatus. Comp. Physiol. Ecol., 4, 118-120.

MUSTAFA S., JAFRI A. K., 1981. Fat and glycogen concentrations in flesh of catfish Heteropneustes fossilis (Bloch) as indicator of living condition. Curr. Sci., 50, 825-826.

MUSTAFA S., MITTAL A.; 1982. Protein, RNA and DNA levels in liver and brain of starved catfish Clarias batrachus. Jap. J. Ichthyol., 28, 396-400.

MUSTAFA S., SHAMS N., 1982. Distribution of nucleic acids in different tissues of catfish Clarias batrachus. Jap. J. Ichthyol., 28, 458-460.

SCHNEIDER W. C., 1957. Determination of nucleic acids in tissues by Pento analysis. In COLOWICK S. P., KAPLAN N. O. Methods in enzymology, vol. 3, Acad. Press, New York, N.Y.

SHAMS N., 1980. Chemical biology of some freshwater fishes. Ph. D. Thesis, Aligarh Muslim University, Aligarh.

WEBB J. M., LEVY H. B., 1955. A sensitive method for the determination of deoxyribonucleic acid in tissues and microorganisms. J. biol. Chem, 213, 107-117.

WILKINS N. P., 1977. Starvation of the herring, Clupea harengus L. : Survival and some gross biochemical changes. Comp. Biochem. Physiol., 23, 503-518. 